\title{
ЗНАННЯ ОРІЄНТОВНІ ЗАСОБИ ПІДТРИМКИ ПРОЦЕСІВ ІНФОРМАЦІЙНОГО СУПРОВОДУ МЕДИЧНОГО ОБСЛУГОВУВАННЯ НАСЕЛЕННЯ (перше повідомлення)
}

\author{
О. П. Мінцер ${ }^{1}$, О. В. Палагін, М. Г. Петренко, В. Ю. Величко, О. Є. Стрижак², \\ Г. Taxepe ${ }^{3}$
}

Інститут кібернетики імені В. М. Глушкова НАН України

Національна медична академія післядипломної освіти імені П. Л. Шупика мОз України ${ }^{1}$ Інститут телекомунікацій і глобального інформаційного простору НАН України ${ }^{2}$

Національний технічний університет України «Київський політехнічний інститут» МОНМС України ${ }^{3}$

Представлені підходи, моделі та засоби формування систем знань з метою підтримки надання інформаційноконсультаційних послуг у медичній практиці лікаря. Визначаються онтологічні моделі, засоби лінгвістичного аналізу та візуалізації відображення об'єктів медичної галузі.

Ключові слова: інформаційна модель, онтологія, морфологія, тезаурус, лінгвістичний аналіз, медичні послуги.

\section{ЗНАНИЯ ОРИЕНТИРОВАННЫЕ СРЕДСТВА ПОДДЕРЖКИ ПРОЦЕССОВ ИНФОРМАЦИОННОГО СОПРОВОЖДЕНИЯ МЕДИЦИНСКОГО ОБСЛУЖИВАНИЯ НАСЕЛЕНИЯ, (первое сообщение)}

О. П. Минцер ${ }^{1}$, О. В. Палагин, Н. Г. Петренко, В. Ю. Величко, А. Е. Стрижак², Г. Taxepe ${ }^{3}$

Институт кибернетики имени В. М. Глушкова НАН Украины Национальная медицинская академия последипломного образования имени П. Л. Шупика МЗ Украины

Институт телекоммуникаций и глобального информационного пространства НАН Украинь ${ }^{2}$ Национальный технический университет Украины «Киевский политехнический институт» MOHМС Украины

Представлены подходы, модели и средства фрормирования систем знаний с целью поддержки предоставления информационно-консультационных услуг в медицинской практике врача. Определяются онтологические модели, средства лингвистического анализа и визуализации отображения объектов медицинской отрасли.

Ключевые слова: информационная модель, онтология, морфология, тезаурус, лингвистический анализ, медицинские услуги.

\section{KNOWLEDGE - ORIENTED TOOLS OF SUPPORT OF PROCESSES OF INFORMATIVE ACCOMPANIMENT OF MEDICAL SERVICE OF POPULATION} (first report)

\author{
O. P. Mintser ${ }^{1}$, O. V. Palahin, M. H. Petrenko, V. Yu. Velychko, O. Ye. Stryzhak ${ }^{2}$, \\ H. Tahere ${ }^{3}$
}

Institute of Cybernetics by V.M. Hlushkov of NAS of Ukraine

National Medical Academy of Post-Graduate Education by P. L. Shupyk of Ministry of Pablyc Health of Ukrainian ${ }^{1}$

Institute for Telecommunications and Global Information Space of NAS of Ukraine ${ }^{2}$ National Technical University of Ukraine 'Kyiv Polytechnic Institute' of Ministry of education and science, young people and sport of Ukrainian ${ }^{3}$ 
There were presented approaches, models and means of forming of the knowledge systems, with the purpose to support of providing of informatively consultative services at medical practice of the doctor. Ontological models, means of linguistic analysis and visualization of reflection of objects of medical industry are determined.

Key words: informative model, ontology, morphology, thesaurus, linguistic analysis, medical services.

Вступ. Основу технологічного базису організації, підтримки і розвитку інформаційно-консультаційної діяльності лікаря складають інтелектуальні інформаційні ресурси (ПР), що агрегують усю сукупність знань, котрі можна використовувати при наданні допомоги хворій людині. Розглядатимемо інформаційне середовище, як сукупність технічних і програмних засобів зберігання, оброблення та передачі інформації, а також відповідного експертного, психологічного та методичного забезпечення. Інформаційна система може розглядатися як інтелектуальна, якщо вона використовує базу знань і розвинену систему програм іiі оброблення.

Умовами успішної роботи в побудові інтелектуальних інформаційних середовищ консультаційного призначення вважаються чітке розуміння мети і напрямку навчальної діяльності (вірна постановка завдання); достатня інформаційна база; повний опис об'єктів предметної області відповідно до технологічної платформи (технологічною платформою можуть бути такі системи: Convera, Exalead, Галактика Zoom, Інформбюро тощо); правильна організація роботи експертів i/або аналітичних груп у заданій темі предметної області $[1,2,4,15,16]$.

Окрім цього необхідно окремо відзначити, що добування і отримання знань про об'єкт можливі лише за умови єдності трьох компонентів:

- сукупності достатніх масивів інформації;

- знань і досвіду експертів і фахівців (аналітиків, методистів, викладачів);

- ефективного аналітичного інструментарію (наприклад, Convera, Exalead, Галактика Zoom, Інформбюро).

При зборі інформації і розробці лінгвістичних ресурсів необхідно враховувати, що об 'єкт дослідження (предметна область, іiї тематичний розділ, процеси, властивості, функціональний опис) є особливим пізнаваним предметом або блоком (реальним або абстрактним), що має важливе функціональне призначення з даної предметної області. Група чи множина об'єктів, що мають зв'язки та пов'язані спільною структурою та функціональністю, можуть бути об'єднані в класи.

Дослідження інформаційного простору з погляду здобуття якнайповнішої інформації про предметну область, зазвичай, передбачає: а) збір інформації про об'єкт в цілому:

- назва об'єкта; його структура та клас; близьке та далеке оточення; його інформаційні агенти й джерела; зв'язки та відношення тощо;

б) збір інформації про об'єкт в контексті мети, що визначена в навчальному процесі, а саме опис об'єктів його тематик як сфер навчальної діяльності та дослідження функціональних властивостей;

в) збір інформації про об'єкт з погляду його визначення (опис сфер його застосування як простору вирішення завдань; опис перетину з іншими об'єктами);

г) аналіз і оцінку зібраної інформації;

г) складання інформаційного портрета об'єкта (агреговані описи, аналітичні записки, структурний опис, перелік властивостей тощо);

д) подальший моніторинг інформаційного поля 3 метою постійного поширення інформаційних описів об'єкта.

Семантичні розширення будуються за класичними правилами складання семантичних мереж $[2,6$, $4,15]$. Такими розширеннями можуть бути: синоніми (прямі і непрямі); антоніми; родо-видові відношення (рід-вид, вид-рід); стосунки частка-иіле; стосунки прочес-об 'єкт/суб 'єкт; схожі поняття; причиннонаслідкові зв'язки (причина-наслідок, наслідок-причина); стосунки підпорядкування (ієрархія підпорядкування); приналежність до груп; стосунки властивість - носій властивості; стосунки процес-знаряддя; стосунки процес-місиее.

Окрім цього, всі зв'язки і розширення, що описують досліджуваний об'єкт, і всі теми дослідження, повинні мати певну вагу в системі здобуття знань.

Одним з ефективних інструментів побудови наочно-орієнтованих онтологій (онтологій предметних областей), за допомогою якого при плануванні й підтримці консультації можна управляти процесом порозуміння лікаря та хворого, виступає тезаурус система понять певної навчальної дисципліни (наочної області) і семантичних відношень між ними. Структура тезауруса і його словникових статей в комп'ютерному варіанті за допомогою спеціально розробленої функціональності дозволяє автоматично отримувати списки семантичних полів (контекстів), наочних областей, що відповідають фрагментам. Експліцитне представлення семантичних стосунків між поняттями також дає можливість вимірювати 
силу того чи іншого семантичного відношення кількісними та якісними методами. Самі семантичні стосунки можуть бути диференційовані далі, що створює багатовимірний інформаційний простір для моделювання поняттєвих комплексів різних рівнів складності $[15,16]$.

Основні постулати. Процес формування інтелектуальних інформаційних ресурсів консультаційного призначення у медицині.

Він будувався на розпізнаванні та добуванні знань 3 природномовних об'єктів (ПМО) та моделюванні інтелектуальної функції людини, а саме, розумінні людиною ПМО [1-5]. При цьому термін розуміння визначався через такі критерії: вміння переказати "своїми" словами, тобто іншими (лексичними, синтаксичними) засобами передати зміст вхідного тексту, вміння відповісти на запитання стосовно певного тексту.

Медична предметна галузь характеризується великою кількість синонімів, нечітким формування висновків, багатозначністю. Саме тому процедура розпізнавання базувалася на засобах формалізації (тобто розробки онтологічних моделей) знань про певну ПдО. Оскільки процедури розпізнавання та розуміння є базовими при лінгвістичній обробці ПМО, розглянемо їх більш детально з методологічної точки зору.

В існуючих IC виокремлюють п'ять основних рівнів розуміння ПМО.

Перший рівень характеризується схемою, яка показує, що будь-які відповіді на запитання система формує тільки на основі прямого змісту, виведеного iз тексту. У лінгвістичному процесорі виконується морфологічний, синтаксичний та семантичний аналіз тексту і запитань, що відносяться до нього. На виході ЛП отримуємо внутрішнє представлення тексту і запитань, з якими може працювати блок виведення. Використовуючи спеціальні процедури, цей блок формує відповіді. Іншими словами, вже розуміння на першому рівні потребує від IC певних засобів представлення даних і виведення на цих даних. Другий рівень. На другому рівні додаються засоби логічного виведення, засновані на інформації, що міститься в тексті. Це різноманітні логіки тексту (часова, просторова, каузальна та ін.), які здатні породжувати інформацію, явно відсутню у тексті. Архітектура IC, за допомогою якої може бути реалізований другий рівень розуміння, повинна мати додаткову базу знань, у якій зберігаються закономірності, що відносяться до часової структури подій, можливої їх просторової організації, каузальної залежності тощо, а логічний блок - усі необхідні засоби для роботи 3 некласичними логіками.
Третій рівень. До засобів другого рівня додаються правила поповнення тексту знаннями системи про середовище. Ці знання в IC, як правило, мають логічний характер і фіксуються у вигляді сценаріїв або процедур іншого типу. Архітектура IC, в якій реалізується розуміння третього рівня, зовнішньо не відрізняється від архітектури IC другого рівня. Проте у логічному блоці повинні бути враховані засоби не тільки для чисто дедуктивного виведення, а й для виведення за сценаріями.

Три перераховані рівні розуміння повністю чи частково реалізовані практично у всіх діючих IC.

Четвертий рівень. На цьому рівні відбувається зміна вмісту бази знань. Вона доповнюється фактами, відомими системі і що вміщуються у тих текстах, які введені в систему. Різні IC відрізняються одна від одної характером правил породження фактів iз знань. Наприклад, в IC, призначених для експертизи в області фармакології, ці правила спираються на методи індуктивного виведення та розпізнавання образів. Правила можуть бути засновані на принципах ймовірностей, розмитих виведень тощо. Але у всіх випадках база знань виявляється апріорно неповною і в таких IC виникають труднощі з пошуком відповідей на запити. Зокрема, в базах знань стає необхідним немонотонне виведення.

П'ятий рівень. На цьому рівні відбувається породження метафоричного знання. Правила породження знань метафоричного рівня, що використовуються для цих цілей, представляють собою спеціальні процедури, що спираються на виведення за аналогією та асоціацією. Відомі в теперішній час схеми виведення за аналогією використовують, як правило, діаграму Лейбниця [2, 4, 9], що відображає тільки частковий випадок суджень за аналогією. Іще менш розроблені схеми асоціативних суджень.

Існують й інші інтерпретації феномену розуміння. Можливо, наприклад, оцінювати рівень розуміння за здатністю системи до пояснення отриманого результату. Тут можливий не тільки рівень пояснення, коли система пояснює, що вона зробила, наприклад, на основі введеного до неї тексту, але і рівень обтрунтування (аргументаціі), коли система обгрунтовує свій результат, показуючи, що він не суперечить тій системі знань і даних, якими вона володіє. На відміну від пояснення, обгрунтування завжди пов'язане із сумою фактів і знань, які визначаються теперішнім моментом існування системи. I введений для розуміння текст в одних станах може бути сприйнятий системою як істинний, а в інших - як хибний. Існуючі IC типу експертних систем, як правило, здатні давати пояснення і лише частково - обгрунтування. 
Особливості аналізу ПМО визначаються спрямованістю на формування поняттєвої структури, тобто на автоматичне добування знань 3 текстів та їх прагматичну інтерпретацію в термінах прикладної задачі. При цьому текст розглядається як об'єкт різних рівнів аналізу: як знакова система, як граматична система і як система знань про світ (предметну область). Кожний рівень має свої особливості, свої засоби вираження i, отже, припускає наявність специфічних методів обробки.

На основі виконаного аналізу моделей та загальних принципів комп'ютерної обробки ПМО, на рисунку 1

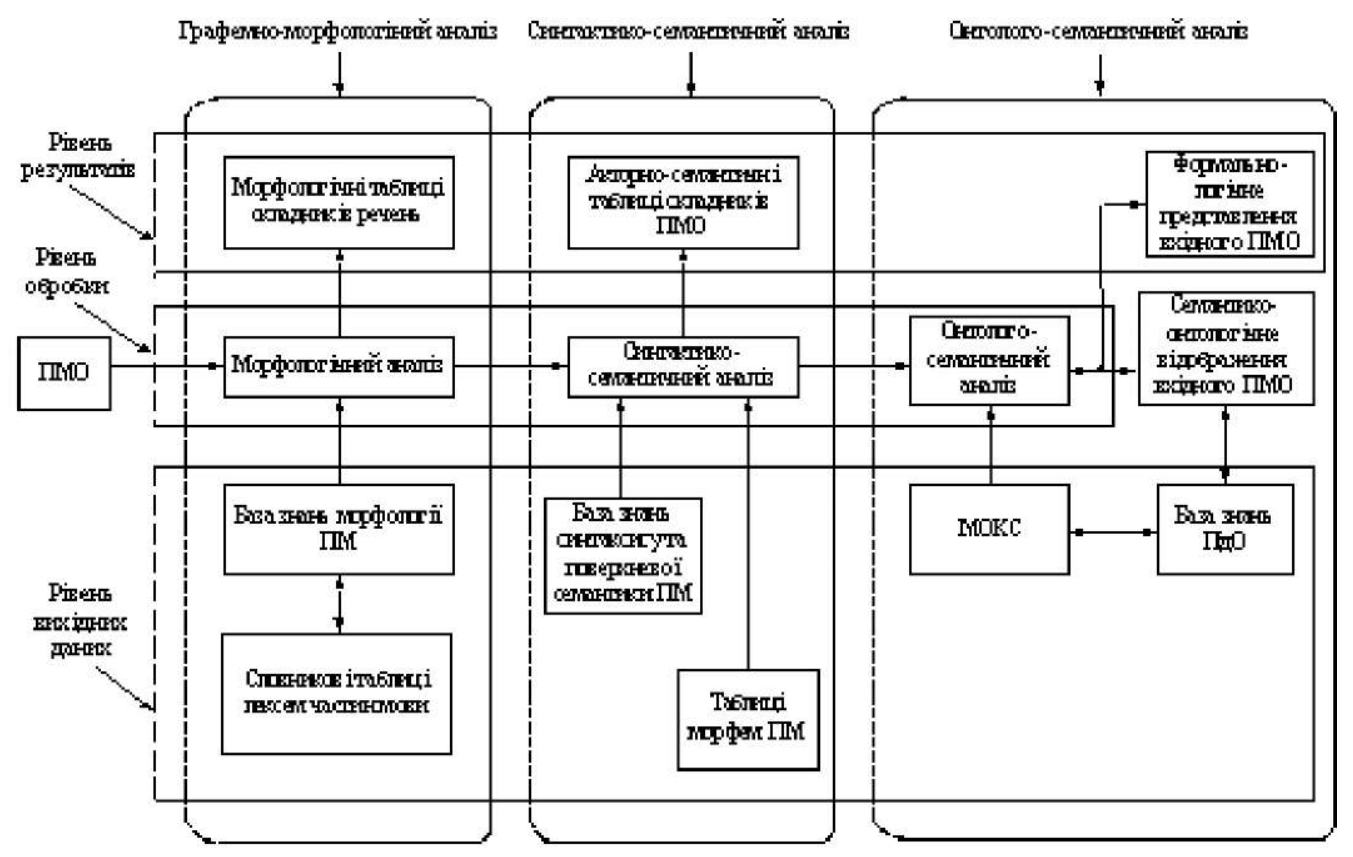

Puc. 1. Структурно-логічна схема етапів лінгвістичного аналізу.

синтезовано структурно-логічну схему етапів лінгвістичного аналізу. На рисунку прийнято наступні скорочення:

- МОКС - мовно-онтологічна картина світу;

- ПМ - природна мова;

- ПМО - природномовний об'єкт.

На схемі база знань ПМ складається з МОКС та баз знань етапів графемного, морфологічного та синтаксичного аналізу. База знань частини реального світу, до якого відноситься лінгвістичний корпус ПМО, відображена в блоці "База знань ПдО".

Метою лінгвістичного аналізу є побудова семантико-онтологічної структури та форм логічного представлення ПМО.

Онтологія, як правило, вміщує ієрархію концепцій предметної області і описує важливі властивості кожної концепції за допомогою механізму " атрибут - значення". Зв'язки між концепціями можуть бути описані за допомогою додаткових логічних тверджень. Константи зіставляються одній або кільком концепціям. Ці і деякі інші властивості онтологій дозволяють використовувати онтології в різних областях знань, підвищуючи ефект від застосування різних методів і способів роботи з інформацією або створюючи на їі основі нові, ще більш ефективні [1]. Особливо ефективність використання онтології визнається в таких дослідницьких областях, як техніка представлення і керування знаннями, моделювання об'єктів і процесів, проектування баз даних, інформаційна інтеграція, виправлення і видобування інформації.

Враховуючи вищенаведене і детальний аналіз, було вирішено будувати ВЛАП як онтолого-керовану систему. Як модель онтології при реалізації ВЛАП було вибрано формальну модель онтології у вигляді $[1,2]$ :

$$
\mathrm{O}=<\mathrm{X}, \mathfrak{R}, \Phi>\text {, }
$$

де $\mathrm{X}$ - кінцева множина концептів (понять, термінів) предметної області, яку представляє онтологія O; $\mathfrak{R}$ - кінцева множина відношень між концептами (поняттями, термінами) заданої предметної області; Ф - кінцева множина функцій інтерпретації (аксіоматизації), заданих на концептах і/або відношеннях онтології О.

Залежно від обмежень, які накладаються X, $\Re$ і $\Phi$, онтологія О може трансформуватися в простий словник предметної області $\mathfrak{R}=0$ і $\Phi=0)$, в пасивний або активний словник предметної області $\mathfrak{R}=0$ і $\Phi \neq$ 0) або просту таксономію понять предметної області $(\Re \neq 0\{$ is_a $\}$ i $\Phi=0)$. 
Модель онтології, як правило, містить три онтологічні компоненти: метаонтологію, предметну онтологію, онтологію задач.

На початку розроблення ВЛАП вирішили, що доцільно почати розроблення онтології з простої таксономії понять предметної області, модель якої має такий вигляд:

$$
\mathrm{O}=<\mathrm{X},\{\text { Is_a }\},\{\}>,
$$

де $\{$ is_a $\}$ - відношення, яке має наперед фіксовану семантику і дозволяє організувати структуру понять онтології у вигляді дерева. Такий підхід має свої переваги і недоліки, але в загальному вигляді $є$ адекватним і зручним способом представлення ієрархії понять.

Розроблена предметна онтологія містить:

1) поняття, що описують предметну область, що стосується віртуальної лабораторії і віртуальних методів проектування;

2) відношення, що семантично значимі для цієї предметної області. Поняття цієї предметної області є специфічними, але відношення - більш універсальними.

Перед початком проектування були сформовані загальні вимоги до онтології:

1) ясність - онтологія повинна ефективно передавати зміст введених термінів;

2) узгодженість - всі поняття і визначення онтології повинні, принаймні, бути логічно не суперечливими;
3) розширюваність - онтологія повинна бути спроектована так, щоб допускати можливість розширювати словник термінів без необхідності ревізії існуючих понять.

Надалі при аналізі літератури [1] і предметної області вимоги до онтології були уточнені:

1) онтологія повинна містити концептуальні, а не епізодичні знання;

2) онтологія повинна бути добре специфікована i внутрішньо узгоджена зі структурою, іменами i вмістом для всіх визначених в ній понять;

3) онтологія повинна бути добре структурована i проста для розуміння і пошуку понять;

4) онтологія повинна обмежуватися конкретною проблемною областю для визначення використаних понять і не повинна вміщувати всю можливу інформацію про предметну область.

Як показує досвід, процес побудови онтології розпадається на ряд підпроцесів. При цьому ці підпроцеси виконуються не послідовно, а порядок їх виконання визначається повнотою і точністю накопичених даних. Але, переважно, спочатку будується глосарій термінів, потім дерева класифікації концептів і діаграми бінарних відношень.

Аналіз предметної області дозволив побудувати верхній рівень онтології, який включає 7 основних концептів (рис. 2).

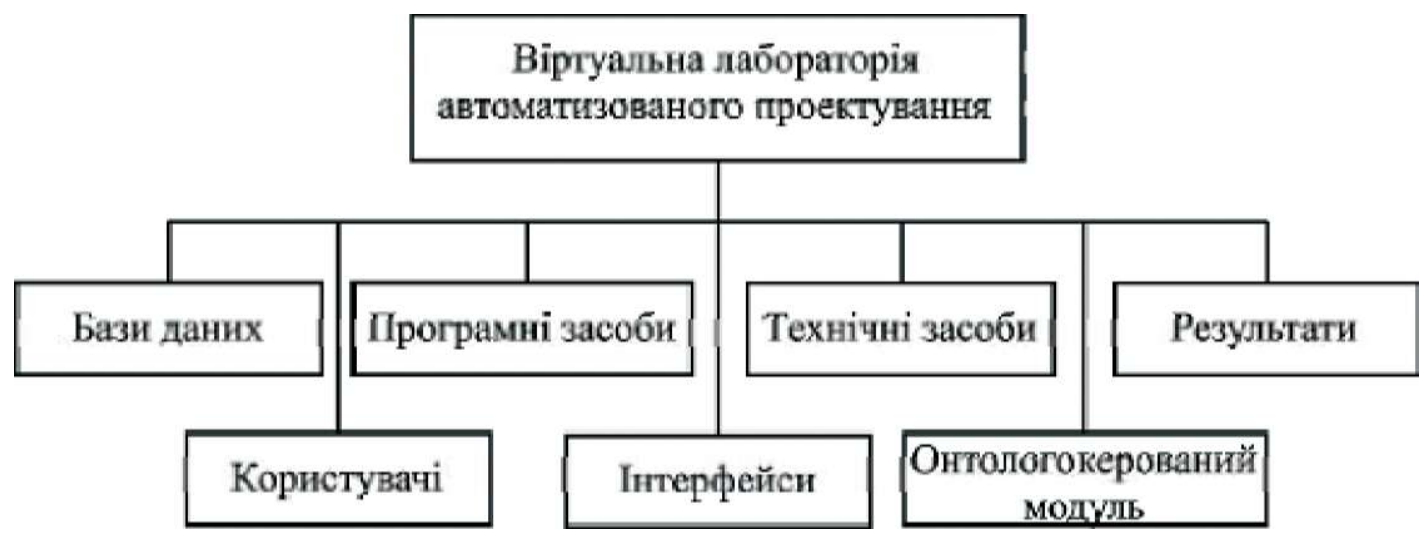

Puc. 2. Верхній рівень онтології.

Згідно предметної області нами створено глосарій, який включає в себе всі терміни (концепти і їх екземпляри, атрибути, дії тощо), що є важливими для предметної області, і їх природно-мовні описи (табл. 1).

Після того, як глосарій у нас досяг "суттєвого" розміру, ми побудували дерева класифікації концептів. Як правило, при цьому використовували відношення типу "підклас" (subclass-of) або "частина" (part-of) а також деякі інші таксономічні відношення. Таким чином, ідентифікуються основні таксономії предмет- ної області. Кожна таксономія, згідно з деякими методологіями, може давати в кінцевому підсумку онтологію.

Наступним кроком була побудова діаграми бінарних відношень (рис. 3), метою створення яких була фіксація відношень між концептами даної онтології. В подальшому ці діаграми можуть послужити вихідним матеріалом для інтеграції різних онтологій.

Узагальнене представлення онтології відображене на рис. 4. 


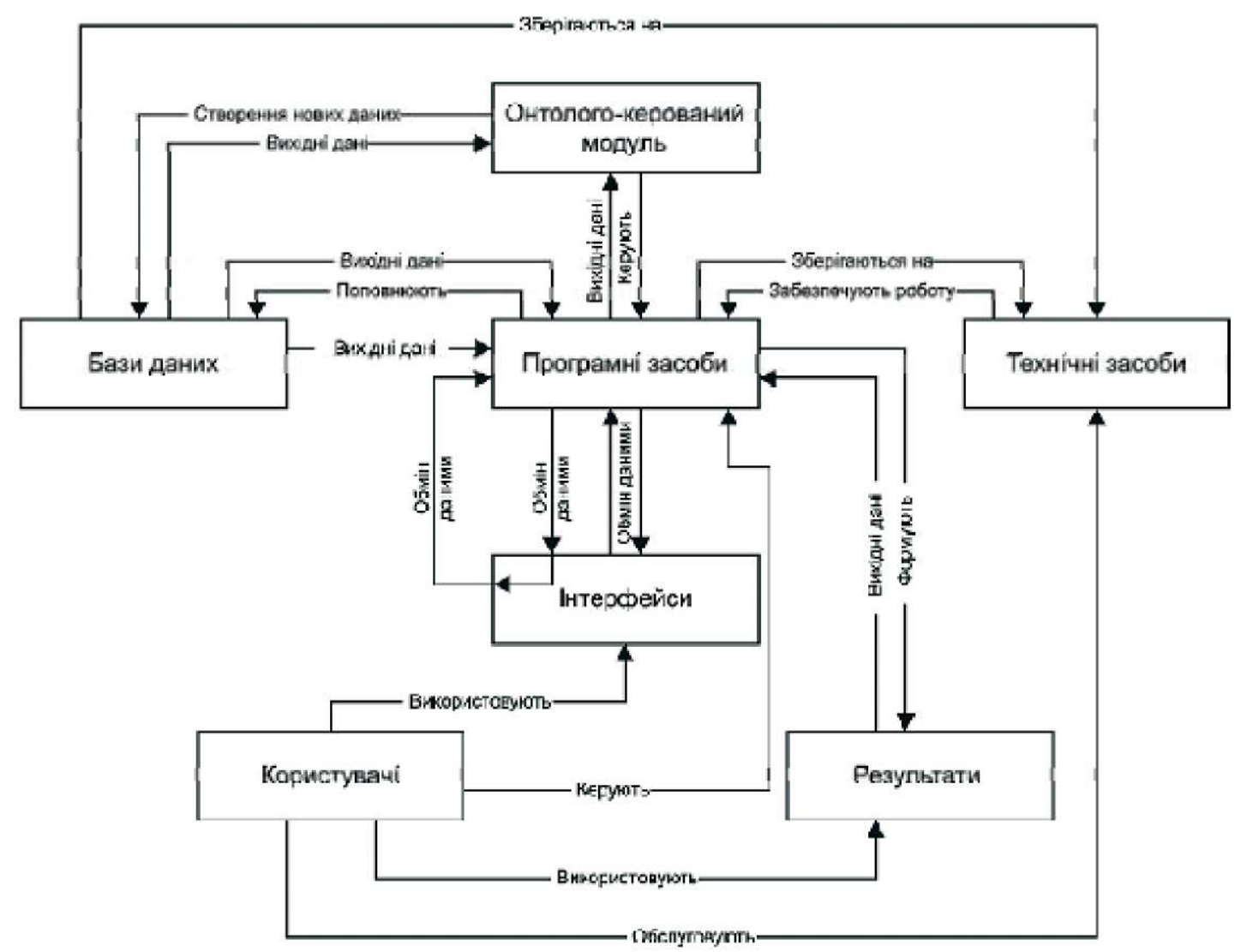

Pис. 3. Діаграма бінарних відношень.

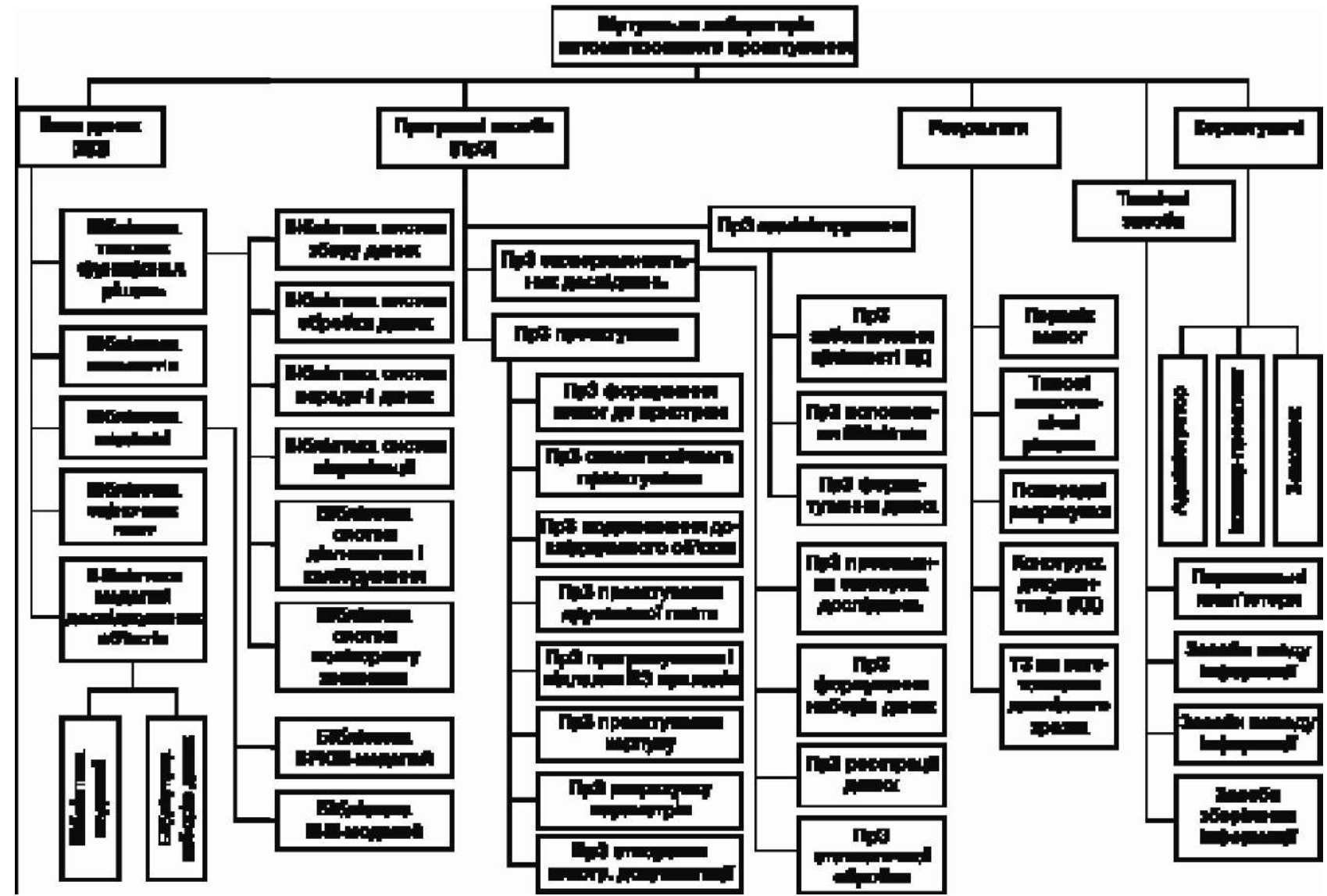

Puc. 4. Узагальнене представлення онтології. 
Таблиця 1. Глосарій термінів предметної області

\begin{tabular}{|c|c|}
\hline Термін & Опис терміну \\
\hline Бази даних & $\begin{array}{l}\text { Файл (або кілька файлів) даних, що зберігаються на ПК або носіях даних і } \\
\text { містять інформацію, яка необхідна для проектування пристроїв. Умовно } \\
\text { поділяється на бібліотеки }\end{array}$ \\
\hline $\begin{array}{l}\text { Бібліотека типових } \\
\text { функціональних рішень }\end{array}$ & $\begin{array}{l}\text { Є частиною Баз даних. Містить типові функціональні рішення для реалізації } \\
\text { функцій (або підсистем) проектованого пристрою }\end{array}$ \\
\hline $\begin{array}{l}\text { Бібліотека систем збору } \\
\text { даних }\end{array}$ & $\begin{array}{l}\text { Є частиною Бібліотеки типових функціональних рішень. Містить варіанти } \\
\text { реалізацій систем збору даних, які призначені для отримання вимірювальної } \\
\text { інформації і її первинної обробки }\end{array}$ \\
\hline $\begin{array}{l}\text { Бібліотека систем обробки } \\
\text { даних }\end{array}$ & $\begin{array}{l}\text { Є частиною Бібліотеки типових функціональних рішень. Містить варіанти } \\
\text { реалізацій систем обробки даних, які призначені для отримання інформації від } \\
\text { систем збору даних і для подальшої їі обробки, а також здійснення підготовки } \\
\text { (нормалізації) обробленої інформації з метою передачі на віддалений пристрій } \\
\text { або збереження у внутрішній пам'яті }\end{array}$ \\
\hline $\begin{array}{l}\text { Бібліотека систем передачі } \\
\text { даних }\end{array}$ & $\begin{array}{l}\text { Є частиною Бібліотеки типових функціональних рішень. Містить варіанти } \\
\text { реалізацій систем передачі даних, які призначені для передачі даних на ПК (в } \\
\text { т.ч. на віддалений) як через кабельне з'єднання, так і через безпровідний зв'язок }\end{array}$ \\
\hline Бібліотека систем візуалізації & $\begin{array}{l}\text { Є частиною Бібліотеки типових функціональних рішень. Містить варіанти } \\
\text { реалізацій систем візуалізації, які призначені для відображення виміряної і } \\
\text { обробленої інформації у формі, зручній для сприйняття користувачем }\end{array}$ \\
\hline $\begin{array}{l}\text { Бібліотека систем } \\
\text { діагностики і калібрування }\end{array}$ & $\begin{array}{l}\text { Є частиною Бібліотеки типових функціональних рішень. Містить варіанти } \\
\text { реалізацій систем калібрування і діагностики, які призначені для перевірки } \\
\text { працездатності пристрою і контролю його параметрів }\end{array}$ \\
\hline $\begin{array}{l}\text { Бібліотека систем } \\
\text { моніторингу живлення }\end{array}$ & $\begin{array}{l}\text { Є частиною Бібліотеки типових функціональних рішень. Містить варіанти } \\
\text { реалізацій систем моніторингу живлення, які призначені для контролю за } \\
\text { параметрами живлення }\end{array}$ \\
\hline Бібліотека елементів & $\begin{array}{l}\text { Є частиною Бази даних. Містить дані про мікроелектронні елементи (напр., } \\
\text { надійність, точність, параметри живлення, довговічність, ціна тощо), які } \\
\text { використовуються для проектування пристроїв. Елементи сортуються як за } \\
\text { виробником,так і за типом }\end{array}$ \\
\hline Бібліотека моделей & Є частиною Бази даних. Містить моделі мікроелектронних елементів \\
\hline Бібліотека SPICE-моделей & $\begin{array}{l}\text { Є частиною Бібліотеки моделей. Містить SPICE-моделі мікроелектронних } \\
\text { елементів }\end{array}$ \\
\hline Бібліотека IBIS-моделей & $\begin{array}{l}\text { Є частиною Бібліотеки моделей. Містить IBIS-моделі мікроелектронних } \\
\text { елементів }\end{array}$ \\
\hline Бібліотека інших моделей & $\begin{array}{l}\text { Є частиною Бібліотеки моделей. Містить моделі мікроелектронних елементів } \\
\text { інших типів (відмінних від SPICE- і IBIS-моделей) }\end{array}$ \\
\hline Бібліотека оціночних плат & $\begin{array}{l}\text { Є частиною Бази даних. Містить віртуальні оціночні плати для оцінювання } \\
\text { параметрів мікроелектронних елементів за допомогою ПК (без використання } \\
\text { будь-якого додаткового обладнання) }\end{array}$ \\
\hline $\begin{array}{l}\text { Бібліотека моделей } \\
\text { досліджуваних об'єктів }\end{array}$ & $\begin{array}{l}\text { Є частиною Бази даних. Містить моделі фізичних об'єктів, параметри яких } \\
\text { планується вимірювати, і відповідні їм набори даних }\end{array}$ \\
\hline $\begin{array}{l}\text { Бібліотека моделей фізичних } \\
\text { об'єктів }\end{array}$ & $\begin{array}{l}\text { Є частиною Бібліотеки моделей досліджуваних об'єктів. Містить моделі } \\
\text { фізичних об'єктів і явищ, параметри яких планується вимірювати за допомогою } \\
\text { пристроїв, які будуть проектуватися. Моделі використовуються для перевірки } \\
\text { функціонування спроектованого пристрою і реалізації віртуальних } \\
\text { експериментальних досліджень }\end{array}$ \\
\hline Бібліотека наборів даних & $\begin{array}{l}\text { Є частиною Бібліотеки моделей досліджуваних об'єктів. Містить набори даних, } \\
\text { які використовуються для перевірки коректності моделей фізичних об'єктів або } \\
\text { явищ і використовуються як вихідні дані для реалізації віртуальних } \\
\text { експериментальних досліджень }\end{array}$ \\
\hline Програмні засоби (Пр3) & $\begin{array}{l}\text { Сукупність всіх програмних засобів (програмного забезпечення), які } \\
\text { використовуються для проектування пристроїв від етапу формування вимог до } \\
\text { пристрою до етапу створення конструкторської документації на спроектований } \\
\text { пристрій, а також додаткові програмні засоби, які використовуються для } \\
\text { адміністрування і поповнення баз даних, для форматування даних, проведення } \\
\text { експериментальних досліджень тощо }\end{array}$ \\
\hline
\end{tabular}


Продовження табл. 1

\begin{tabular}{|c|c|}
\hline Термін & Опис терміну \\
\hline $\begin{array}{l}\text { Програмні засоби } \\
\text { проектування }\end{array}$ & $\begin{array}{l}\text { Є частиною Пр3. Використовуються для безпосереднього проектування } \\
\text { пристроїв на етапах формування вимог до пристрою, схемотехнічного } \\
\text { проектування, моделювання досліджуваного об'єкта, проектування друкованої } \\
\text { плати, проектування корпусу, розрахунку параметрів, створення } \\
\text { конструкторської документації на спроектований пристрій тощо. }\end{array}$ \\
\hline $\begin{array}{l}\text { Програмні засоби } \\
\text { формування вимог до } \\
\text { пристрою }\end{array}$ & $\begin{array}{l}\text { Є частиною Пр3 проектування. Використовуються для формування вимог до } \\
\text { параметрів, характеристик і властивостей пристрою, що проектується }\end{array}$ \\
\hline $\begin{array}{l}\text { Програмні засоби } \\
\text { схемотехнічного } \\
\text { проектування }\end{array}$ & $\begin{array}{l}\text { Є частиною Пр3 проектування. Використовуються для схемотехнічного } \\
\text { проектування пристрою } 3 \text { врахуванням заданих вимог }\end{array}$ \\
\hline $\begin{array}{l}\text { Програмні засоби } \\
\text { моделювання досліджуваного } \\
\text { об'єкта }\end{array}$ & $\begin{array}{l}\text { Є частиною ПрЗ проектування. Використовуються для моделювання фізичного } \\
\text { об'єкта або явища, параметри якого планується вимірювати за допомогою } \\
\text { пристрою, що проектується }\end{array}$ \\
\hline $\begin{array}{l}\text { Програмні засоби } \\
\text { проектування друкованої } \\
\text { плати }\end{array}$ & $\begin{array}{l}\text { Є частиною Пр3 проектування. Використовуються для проектування друкованої } \\
\text { плати пристрою на основі результатів схемотехнічного проектування }\end{array}$ \\
\hline $\begin{array}{l}\text { Програмні засоби } \\
\text { програмування і відладки ПЗ } \\
\text { приладів }\end{array}$ & $\begin{array}{l}\text { Є частиною Пр3 проектування. Використовуються для програмування } \\
\text { розроблюваних приладів, перевірки коду і завантаження коду в прилад. Як } \\
\text { правило, в склад цих засобів входять: бібліотеки підпрограм, компілятори мов } \\
\text { програмування, емулятор для перевірки коду, дебагер для відладки коду, } \\
\text { завантажувач коду тощо }\end{array}$ \\
\hline $\begin{array}{l}\text { Програмні засоби } \\
\text { проектування корпусу }\end{array}$ & $\begin{array}{l}\text { Є частиною Пр3 проектування. Використовуються для проектування } \\
\text { зовнішнього вигляду корпусу пристрою, розташування елементів всередині } \\
\text { корпусу і тримірного відображення корпусу приладу }\end{array}$ \\
\hline $\begin{array}{l}\text { Програмні засоби розрахунку } \\
\text { параметрів спроектованого } \\
\text { пристрою }\end{array}$ & $\begin{array}{l}\text { Є частиною Пр3 проектування. Використовуються для розрахунку параметрів } \\
\text { спроектованого пристрою на основі спроектованої схеми і вибраних } \\
\text { мікроелектронних елементів. Як приклад, до параметрів можна віднести } \\
\text { надійність, точність (похибка), швидкодію, ціну тощо. }\end{array}$ \\
\hline $\begin{array}{l}\text { Програмні засоби створення } \\
\text { конструкторської } \\
\text { документації }\end{array}$ & $\begin{array}{l}\text { Є частиною Пр3 проектування. Використовуються для створення повного } \\
\text { комплекту конструкторської документації на спроектований пристрій згідно } 3 \\
\text { існуючими стандартами щодо конструкторської документації }\end{array}$ \\
\hline $\begin{array}{l}\text { Програмні засоби } \\
\text { адміністрування }\end{array}$ & $\begin{array}{l}\text { Є частиною Пр3. Використовуються для створення умов функціонування Пр3 } \\
\text { проектування шляхом забезпечення цілісності Бази даних, поповнення бібліотек } \\
\text { i форматування даних }\end{array}$ \\
\hline $\begin{array}{l}\text { Програмні засоби } \\
\text { забезпечення цілісності бази } \\
\text { даних }\end{array}$ & $\begin{array}{l}\text { Є частиною ПрЗ адміністрування. Використовуються для забезпечення } \\
\text { цілісності Бази даних шляхом виконання процедур резервування даних, } \\
\text { діагностики стану Бази даних тощо }\end{array}$ \\
\hline $\begin{array}{l}\text { Програмні засоби } \\
\text { поповнення бібліотек }\end{array}$ & $\begin{array}{l}\text { Є частиною Пр3 адміністрування. Використовуються для поповнення бібліотек. } \\
\text { Поповнення може здійснюватися в ручному режимі, в режимі вводу з носіїв } \\
\text { даних, в режимі вводу з мережі Internet (як з визначених сайтів, так і в режимі } \\
\text { автоматичного пошуку) }\end{array}$ \\
\hline $\begin{array}{l}\text { Програмні засоби } \\
\text { форматування даних }\end{array}$ & $\begin{array}{l}\text { Є частиною Пр3 адміністрування. Використовуються для форматування даних, } \\
\text { якщо вони надійшли у форматі, відмінному від формату даних в бібліотеках }\end{array}$ \\
\hline $\begin{array}{l}\text { Програмні засоби } \\
\text { експериментальних } \\
\text { досліджень }\end{array}$ & $\begin{array}{l}\text { Є частиною ПрЗ. Використовуються для проведення експериментальних } \\
\text { досліджень (віртуальних), формування необхідних вхідних наборів даних для } \\
\text { цих досліджень у випадку відсутності останніх та статистичної обробки } \\
\text { отриманих результатів }\end{array}$ \\
\hline $\begin{array}{l}\text { Програмні засоби проведення } \\
\text { експериментальних } \\
\text { досліджень }\end{array}$ & $\begin{array}{l}\text { Є частиною Пр3 експериментальних досліджень. Використовуються для } \\
\text { проведення віртуальних експериментальних досліджень. Як вхідні дані } \\
\text { використовуються модель досліджуваного об'єкта і відповідні їй набори даних }\end{array}$ \\
\hline $\begin{array}{l}\text { Програмні засоби } \\
\text { формування наборів даних }\end{array}$ & $\begin{array}{l}\text { Є частиною Пр3 експериментальних досліджень. Використовуються для } \\
\text { формування наборів даних для моделі досліджуваного об'єкту у випадку, якщо } \\
\text { такі дані відсутні }\end{array}$ \\
\hline
\end{tabular}


Продовження табл. 1

\begin{tabular}{|c|c|}
\hline Термін & Опис терміну \\
\hline $\begin{array}{l}\text { Програмні засоби реєстрації } \\
\text { даних }\end{array}$ & $\begin{array}{l}\text { Є частиною Пр3 експериментальних досліджень. Використовуються для } \\
\text { реєстрації вхідних і вихідних даних при проведенні експериментальних } \\
\text { (віртуальних) досліджень }\end{array}$ \\
\hline $\begin{array}{l}\text { Програмні засоби } \\
\text { статистичної обробки }\end{array}$ & $\begin{array}{l}\text { Є частиною Пр3 експериментальних досліджень. Використовуються для } \\
\text { статистичної обробки зібраних даних і пошуку певних закономірностей }\end{array}$ \\
\hline Користувач & $\begin{array}{l}\text { Людина (він/вона), яка безпосередньо або за допомогою інших спеціалістів } \\
\text { використовує ВЛАП для проектування пристроїв } 3 \text { метою задоволення своїх } \\
\text { потреб або потреб інших осіб }\end{array}$ \\
\hline Адміністратор & $\begin{array}{l}\text { Є частиною Користувача. Людина (він/вона), яка використовує свої спеціальні } \\
\text { знання і Пр3 адміністрування для створення нормальних умов для виконання } \\
\text { робіт по проектуванню. Також повинен слідкувати за працездатністю Сервера. У } \\
\text { деяких випадках може виконувати функції Інженера-проектанта }\end{array}$ \\
\hline Інженер-проектант & $\begin{array}{l}\text { Є частиною Користувача. Людина (він/вона), яка використовує свої спеціальні } \\
\text { знання і Пр3 проектування для безпосереднього проектування пристроїв. Також } \\
\text { використовує Пр3 проведення експериментальних досліджень для проведення } \\
\text { експериментальних досліджень, для перевірки функціонування спроектованого } \\
\text { пристрою, для перевірки робочих гіпотез тощо. Може виконувати функції } \\
\text { Адміністратора }\end{array}$ \\
\hline Замовник & $\begin{array}{l}\text { Є частиною Користувача. Формує всі вимоги (або частину) до параметрів, } \\
\text { характеристик і властивостей пристрою, який проектується }\end{array}$ \\
\hline Технічні засоби & $\begin{array}{l}\text { Обладнання, яке використовується для забезпечення роботи всіх Пр3, } \\
\text { збереження інформації і виконання функцій Користувачами } 3 \text { метою } \\
\text { проектування пристроїв }\end{array}$ \\
\hline Персональний комп'ютер & Є частиною Технічних засобів. Призначені для зберігання і виконання всіх Пр3 \\
\hline Сервер & $\begin{array}{l}\text { Є частиною Персонального комп'ютера. Призначений для зберігання і } \\
\text { виконання всіх Програмних засобів, а також для зберігання Бази даних і } \\
\text { резервних копій. Як правило, використовується як робоче місце Адміністратора. } \\
\text { Може виконувати одночасно роль Робочої станції }\end{array}$ \\
\hline Робоча станція & $\begin{array}{l}\text { Є частиною Персонального комп'ютера. Призначена для виконання (інколи і для } \\
\text { зберігання) програмних Засобів проектування і програмних Засобів } \\
\text { експериментальних досліджень. Як правило, використовуються як робоче місце } \\
\text { Інженера-проектанта або Замовника }\end{array}$ \\
\hline Засоби вводу інформації & $\begin{array}{l}\text { Є частиною Технічних засобів. Призначенні для введення інформації, яка } \\
\text { необхідна для проектування пристроїв, і мають в своєму складі клавіатури, } \\
\text { маніпулятори, сканери, приводи різних типів носіїв даних (гнучкі диски, } \\
\text { оптичні, zip, dvd) тощо }\end{array}$ \\
\hline Засоби виводу інформації & $\begin{array}{l}\text { Є частиною Технічних засобів. Призначенні для виведення інформації, яка } \\
\text { отримана в результаті проектування або з метою створення резервних копій. } \\
\text { Мають в своєму складі принтери, плотери, мультимедійні проектори, записуючі } \\
\text { приводи різних типів носіїв даних (гнучкі диски, оптичні, zip, dvd) тощо }\end{array}$ \\
\hline Засоби зберігання інформації & $\begin{array}{l}\text { Є частиною Технічних засобів. Призначенні для збереження інформації, яка } \\
\text { необхідна для проектування пристроїв або з метою створення резервних копій. } \\
\text { Мають в своєму складі приводи різних типів носіїв даних (жорсткі диски, гнучкі } \\
\text { диски, оптичні, zip, dvd) }\end{array}$ \\
\hline Результати & $\begin{array}{l}\text { Сукупність друкованих матеріалів і файлів на носіях даних, які описують } \\
\text { спроектований пристрій як в цілому, так і результати, що отримано в кінці } \\
\text { кожного етапу проектування. Можуть бути представлені як в паперовому, так і в } \\
\text { електронному варіантах }\end{array}$ \\
\hline Список вимог до пристрою & $\begin{array}{l}\text { Є частиною Результатів. Являє собою список всіх вимог до майбутнього } \\
\text { пристрою. Всі вимоги (або їх частина) задаються (надаються) Замовником }\end{array}$ \\
\hline $\begin{array}{l}\text { Типові схемотехнічні } \\
\text { рішення }\end{array}$ & $\begin{array}{l}\text { Є частиною Результатів. Являють собою певні схемотехнічні рішення реалізації } \\
\text { пристрою згідно із задним списком вимог }\end{array}$ \\
\hline Проект схеми пристрою & Є частиною Результатів. Являє собою проект схеми пристрою \\
\hline Проект друкованої плати & Є частиною Результатів. Являє собою проект друкованої плати \\
\hline Проект корпусу пристрою & Є частиною Результатів. Являє собою проект корпусу пристрою \\
\hline
\end{tabular}


Продовження табл. 1

\begin{tabular}{|c|c|}
\hline Термін & Опис терміну \\
\hline $\begin{array}{l}\text { Список розрахованих } \\
\text { параметрів }\end{array}$ & $\begin{array}{l}\text { Є частиною Результатів. Являє собою список розрахованих параметрів } \\
\text { спроектованого пристрою (наприклад, точність, швидкодія, надійність, ціна } \\
\text { тощо) }\end{array}$ \\
\hline $\begin{array}{l}\text { Комплект конструкторської } \\
\text { документації }\end{array}$ & $\begin{array}{l}\text { Є частиною Результатів. Являє собою повний комплект конструкторської } \\
\text { документації на спроектований пристрій, оформленої згідно } 3 \text { діючими } \\
\text { стандартами }\end{array}$ \\
\hline $\begin{array}{l}\text { Т3 на виготовлення } \\
\text { дослідного зразка }\end{array}$ & $\begin{array}{l}\text { Є частиною Результатів. Являє собою належним чином оформлене технічне } \\
\text { завдання на виготовлення дослідного зразка спроектованого пристрою }\end{array}$ \\
\hline Інтерфейси & $\begin{array}{l}\text { Сукупність програмних модулів, які забезпечують обмін інформацією всередині } \\
\text { між програмними засобами, між користувачем і віртуальною лабораторією }\end{array}$ \\
\hline Людино-машинні інтерфейси & $\begin{array}{l}\text { Є частиною Інтерфейсів. Призначені для забезпечення обміну інформацією між } \\
\text { Програмними засобами і Користувачами }\end{array}$ \\
\hline Програмні інтерфейси & $\begin{array}{l}\text { Є частиною Інтерфейсів. Призначені для забезпечення обміну інформацією між } \\
\text { Програмними засобами. Поділяються на внутрішні і зовнішні }\end{array}$ \\
\hline $\begin{array}{l}\text { Внутрішні програмні } \\
\text { інтерфейси }\end{array}$ & $\begin{array}{l}\text { С частиною Програмних інтерфейсів. Призначені для забезпечення обміну } \\
\text { інформацією всередині ВЛАП між Програмними засобами лабораторії }\end{array}$ \\
\hline $\begin{array}{l}\text { Зовнішні програмні } \\
\text { інтерфейси }\end{array}$ & $\begin{array}{l}\text { Є частиною Програмних інтерфейсів. Призначені для забезпечення обміну } \\
\text { iнформацією між Програмними засобами ВЛАП і Програмними засобами, які не } \\
\text { входять в склад ВЛАП }\end{array}$ \\
\hline Онтологокерований модуль & $\begin{array}{l}\text { Представляє онтологію як спеціальний програмний модуль, який призначений } \\
\text { для організації роботи ВЛАП як відкритої онтолого-керованої інформаційної } \\
\text { системи }\end{array}$ \\
\hline
\end{tabular}

Таксономії предметної області

При побудові, як правило, використовували відношен ня типу "підклас" (subclass-of) або "частина" (part-of).

1. База даних

1.1. Бібліотека типових функціональних рішень

1.1.1. Бібліотека систем збору даних

1.1.2. Бібліотека систем обробки даних

1.1.3. Бібліотека систем передачі даних

1.1.4. Бібліотека систем візуалізації

1.1.5. Бібліотека систем діагностики і калібрування

1.1.6. Бібліотека систем моніторингу живлення

1.2. Бібліотека елементів

1.2.1. По виробнику (sort)

1.2.2. По типу (sort)

1.3. Бібліотека моделей

1.3.1. Бібліотека SPICE-моделей

1.3.2. Бібліотека IBIS-моделей

1.3.3. Бібліотека інших типів моделей

1.4. Бібліотека оціночних плат (віртуальних)

1.5. Бібліотека літератури

1.5.1. Статті

1.5.2. Книжки

1.5.3. Посилання

1.6. Бібліотека інтерактивних засобів

1.6.1. По типу елементів (sort)

1.6.2. По виробнику (sort)

1.7. Бібліотека моделей досліджуваних об'єктів

1.7.1. Бібліотека моделей

1.7.2. Бібліотека наборів даних
2. Програмні засоби

2.1. Програмні засоби проектування

2.1.1. Програмні засоби формування вимог до пристрою

2.1.2. Програмні засоби схемотехнічного проектування

2.1.3. Програмні засоби моделювання досліджуваного об'єкта

2.1.4. Програмні засоби проектування друкованої плати

2.1.5. Програмні засоби програмування і відладки ПЗ приладів

2.1.6. Програмні засоби проектування корпусу

2.1.7. Програмні засоби розрахунку параметрів спроектованого пристрою

2.1.8. Програмні засоби створення конструкторської документації

2.2. Програмні засоби адміністрування

2.2.1. Програмні засоби забезпечення цілісності бази даних

2.2.2. Програмні засоби поповнення бібліотек

2.2.2.1. Програмні засоби ручного вводу даних

2.2.2.2. Програмні засоби вводу з носіїв даних

2.2.2.3. Програмні засоби вводу з Internet

2.2.2.3.1. Ввід з визначених сайтів

2.2.2.3.2. Автоматичний пошук в Internet

2.2.3. Програмні засоби форматування даних

2.3. Програмні засоби експериментальних досліджень

2.3.1. Програмні засоби проведення експериментальних досліджень 


\subsection{2. Програмні засоби формування даних}

2.3.3. Програмні засоби реєстрації даних

2.3.4. Програмні засоби статистичної обробки

3. Технічні засоби

3.1. Персональні комп'ютери

3.1.1. Сервер

3.1.2. Робоча станція

3.2. Засоби вводу інформації

3.3. Засоби виведення інформації

3.4. Засоби зберігання інформації

4. Результати

4.1. Перелік вимог до пристрою

4.2. Типові схемотехнічні рішення

4.3. Попередні розрахунки параметрів пристрою

4.4. Проект друкованої плати

4.5. Проект корпусу

4.6. Список розрахованих параметрів

4.7. Комплект конструкторської документації

5. Користувачі

5.1. Адміністратор

5.2. Інженер-проектант

5.3. Замовник

6. Інтерфейси

6.1. Людино-машинні інтерфейси

6.2. Програмні інтерфейси

6.2.1. Внутрішні програмні інтерфейси

6.2.2. Зовнішні програмні інтерфейси

7. Онтологокерований модуль.

Моделі програмних засобів. 3 метою підвищення ефективності розробки моделі програмного засобу візуалізації об'єктів проектування онтологічного опису, продуктивно застосовували спеціальну мову моделювання - UML (unified model language).

Серед інструментів для розробки діаграм UML було обрано Rational Rose. Цей інструмент було розроблено корпорацією Rational Software Corporation спеціально для розробки UML-діаграм.

Отже, для опису функціональної частини програмного засобу та варіантів його використання було розроблено 2 діаграми варіантів використання (use-case diagram). В ході аналізу визначили, яким функціоналом має володіти програма для забезпечення повноцінної роботи аналітика:

а) відображення всього графу;

б) відображення найкоротших шляхів між двома вибраними користувачем вершинами;

в) відображення повного графу, побудованого відносно вибраної користувачем вершини та обмеженого вибраною користувачем глибиною;

г) у користувача має бути можливість переглядати весь список вершин, які присутні у графі; д) редагування вершин та ребер;

е) масштабування;

ж) можливість збереження та завантаження графу у форматі XML;

3) додання до графу нових вершин та зв'язків;

i) видалення вершин та ребер;

к) управління відображенням імен та деяких інших властивостей вершин і ребер на графіку;

л) можливість зміни розташування вершин самим користувачем так, як він того забажає.

Виділено два варіанти початку роботи з програмою:

а) запуск програми ініціює безпосередньо користувач;

б) запуск програми ініціюється опосередковано користувачем через інший програмний засіб, що використовується користувачем в комплексі із інструментом, що розробляється.

Згідно 3 цими варіантами та виявленим аналізом необхідним функціоналом було розроблено дві діаграми варіантів використання (use-case diagram), що представлені на рис. 5 і 6.

В результаті аналізу задачі виявлено три ключові сутності - вершина, ребро та графік, на якому граф має відображатися. Також було прийнято рішення, що сам граф не варто розглядати як сутність, тому що усі властивості графу повністю відображаються його складовими, тобто вершинами та ребрами.

Згідно з теорією графів та потреб користувача розглядали вершини як об'єкти, що мають такі атрибути:

а) ім'я;

б) унікальний в межах поточного графу ідентифікатор;
в) форма;
г) колір;
д) координату $\mathrm{X}$;
е) координату Y;
ж) список інцидентних ребер;
3) список суміжних вершин;
i) список батьківських вершин;
к) список дочірніх вершин;
л) рівень глибини.

Аналогічно було визначено атрибути для ребер:

a) ім'я;

б) унікальний в межах поточного графу ідентифікатор;

в) колір;

г) вага;

д) перша інцидентна вершина;

е) друга інцидентна вершина.

Для графіка було визначено такі атрибути:

а) режим розташування графу (визначається користувачем та відповідає за спосіб, метод візуалізаціі);

б) список вершин, що присутні на графіку; 


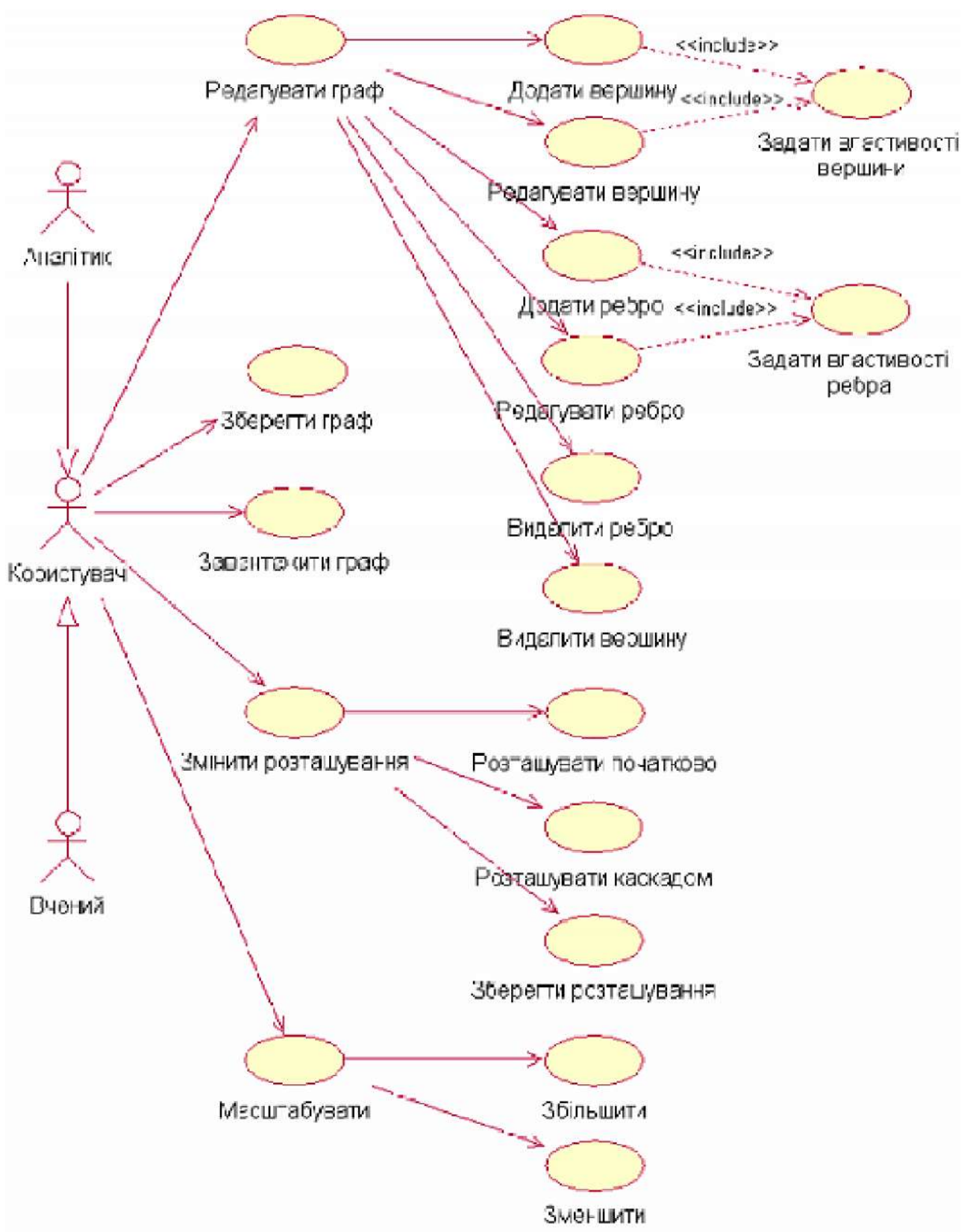

Puc. 5. Перша діаграма варіантів використання.

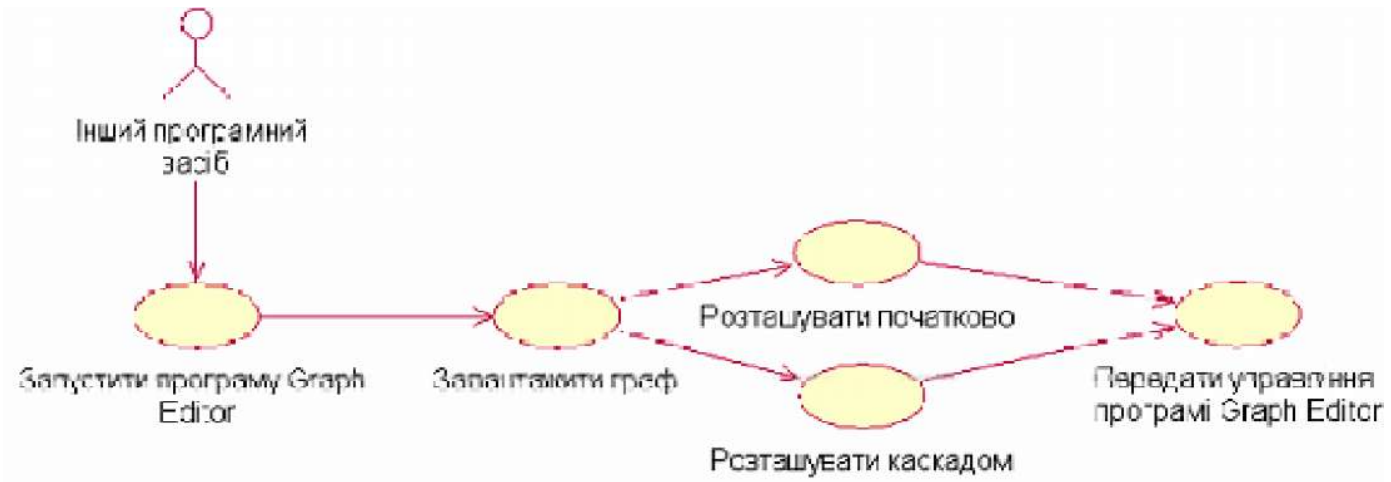

Puc. 6. Друга діаграма варіантів використання. 
в) список ребер, що присутні на графіку;

г) список кореневих вершин, що присутні на графіку.

Згідно із прийнятим шаблоном MVC та визначеними атрибутами сутностей, була розроблена діаграма класів. У спрощеному вигляді діаграма представлена на рис. 7.

Одним з головних вимог до онтологізованих (знання - орієнтованих) систем розробки баз знань навчального призначення (з формуванням термінів $\mathrm{i}$ понять $з$ природно-мовних навчальних ресурсів) $є$ наявність формалізованої методики автоматизованої побудови онтології довільної предметної дисципліни, діючої інформаційної й функціональної моделі і відповідних програмно реалізованих інструменталь- них засобів. При цьому передбачається, що як джерело онтологічних знань виступає лінгвістичний корпус текстів множини навчальних ресурсів (російською й українською мовами) із заданої дисципліни.

Для обробки текстів українською мовою відомі тільки лінгвістичні програмні процесори, що використовуються в основному для побудови лексикографічних систем. Крім того, окремою проблемою для всіх систем-прототипів є лінгвістична обробка великих обсягів текстової інформації за реальний час.

Схема функціональної моделі процесу проектування бази знань навчального призначення представлена на рис. 8.
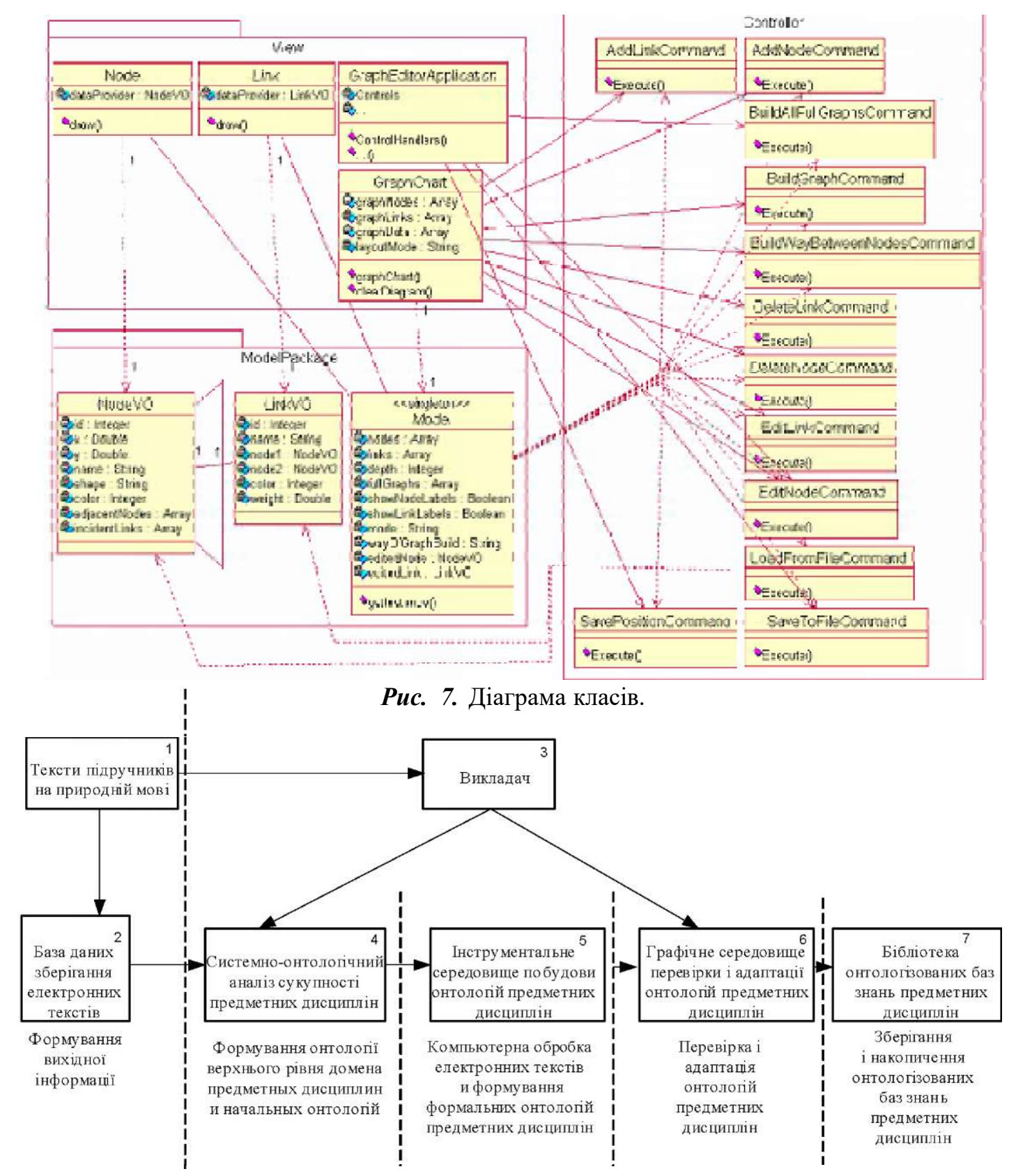

Puc. 8. Функціональна модель процесу проектування БЗНП. 
Процес проектування БЗНП орієнтований на ефективну програмну підтримку реалізації найбільш трудомістких процедур (блоки 1, 2 рис. 8).

У блоці 4 виконується системно-онтологічний аналіз сукупності предметних дисциплін і формування онтології верхнього рівня.

У блоці 5 виконується комп'ютерна обробка великих обсягів текстової інформації й формується онтологія предметної дисципліни. Побудова множини понять предметної дисципліни є першим кроком у проектуванні БЗНП.

Розглянемо автоматизований метод формування множини понять. Для автоматизованої побудови поняттєвого апарата з текстів предметної області використовується пошук і виділення субстантивних іменних словосполучень, що виражаються схемою: узгоджуване слово + іменник. У цій моделі іменник $є$ головним словом, а узгоджуване слово - залежним і може виражатися як прикметником, так і іменником. Словосполучення можуть включати у свій склад також прийменники й сурядні сполучники. Кількість слів в іменних словосполученнях звичайно коливається від двох до п'ятнадцяти й у середньому становить три слова.

Автоматичне виділення однослівних і багатослівних термінів, крім шаблонів, використовує результати синтаксично-семантичного аналізу тексту. Розпізнання поверхневих семантичних відносин здійснюється за допомогою аналізу флексій повнозначних слів, з огляду на прийменники й сполучники, без попереднього повного граматичного розбору й побудови синтаксичних відносин, які використовуються в традиційній граматиці.

Процедура виділення термінів з тексту включає два основних етапи. На першому етапі відбувається безпосередній пошук у тексті слів і словосполучень кандидатів у терміни. Як однослівні терміни вибираються іменники й абревіатури. Багатослівні терміни формуються за допомогою певних типів відносин між словами речення, шляхом поступового приєднання слів до однослівного терміна-іменника. Для термінів - іменних словосполучень використовуються наступні основні типи відносин між словами: об 'єктне, приналежність (між двома іменниками), означальне (між прикметником і іменником), однорідні слова (між двома іменниками або двома прикметниками). Виділені групи слів перевіряються на відповідність заданим шаблонам. Порядок розташування в реченні слів, що утворять термін, може точно не відповідати заданому шаблону, але обов'язковою умовою виділення терміна є відповідність відно- син між словами певним типам відносин. Це дозволяє, наприклад, з речення "Побудова онтологї̈зазначеної предметної області" виділити термін "онтологія предметної області".

На другому етапі список кандидатів у терміни фільтрується: враховується значимість виділених словосполучень (наближеність у дереві розбору до підмета або присудка речення) і частота, з якою вони зустрічаються в тексті.

Наведені принципи автоматичної побудови списку можливих термінів реалізовані для української й російської мов у програмі "Конспект".

У блоці 6 здійснюється перевірка й адаптація онтології дисципліни в інтерактивному режимі і включає роботу викладача з онтологією в автоматизованому графічному середовищі.

У блоці 7 здійснюється накопичення онтологічних баз знань предметних дисциплін, використання яких дозволить забезпечити однаковість подання поняттєвих структур за тематикою. Електронний інформаційний консультаційний ресурс, побудований на основі онтологічного підходу автоматизованим способом на основі даної предметної дисципліни, інтегрує загальні концепти і їх зв'язки й у цьому змісті $\epsilon$ загальнозначущим, загальноприйнятим, побудованим 3 істотним зменшенням суб'єктивного фактора.

Побудована відповідно до функціональної моделі програмна модель дозволить істотно зменшити часові витрати на побудову баз знань медичного призначення за рахунок великого ступеня автоматизації робіт, що виконуються у блоці 5 (рис. 8).

Інтегровані інструментальні засоби, що реалізують функціональну модель процесу проектування БЗНП, перебувають у стадії проектування й розробки. Окремі модулі системи вже можуть бути використані для розв'язання практичних задач.

Знання при використанні БЗНП будуть представлятися за допомогою єдиної системи понять, що однозначно інтерпретуються, при цьому систему понять легше сконструювати несуперечливою, повною, структурованою, такою, що адекватно відображає дійсність.

Використання в процесі проектування інформаційних ресурсів автоматизованого лінгво-семантичного аналізу великих обсягів текстової інформації природною мовою (російською й українською), а також структурування й обробка термінів (понять) із заданої предметної дисципліни, дозволяє істотно поліпшити якість і знизити часові витрати на складання баз знань навчального призначення. Удосконалення запропонованого підходу передбачається на основі досвіду 
експлуатації системи підтримки автоматизованої побудови БЗНП (рис. 9).

Інформаційна модель лінгвістичного аналізу. Блок-схема узагальненого алгоритму лінгвістичного аналізу та формалізації деякого ПМО (рис. 10) являє собою послідовність етапів графемно-морфологічного, синтаксичного, об'єктово-семантичного, акторно-семантичного, онтологічного, онтолого-семантичного та формально-логічного аналізу. Деякі аспекти безпосереднього лінгвістичного аналізу описані вище та в ряді праць [5-8].

На рис. 10 прийнято такі скорочення: ПМО - природномовний об'єкт; W - послідовність словоформ, що описують ПМО; С - послідовність синтаксич-

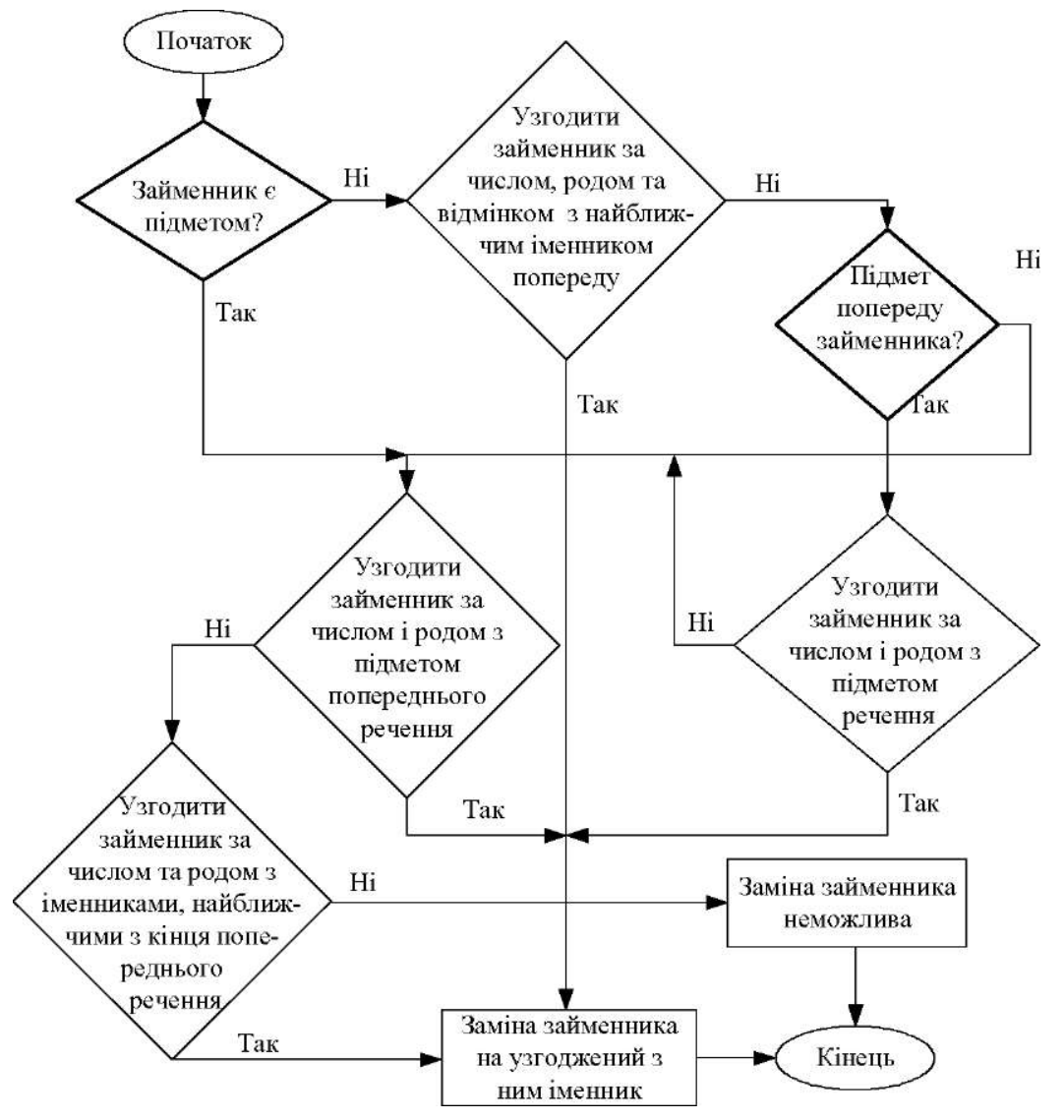

Puc. 9. Блок-схема алгоритму заміни займенників.

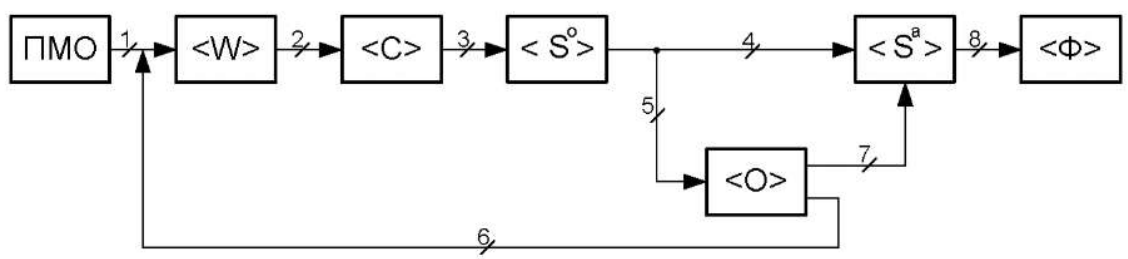

Puc. 10. Блок-схема лінгвістичного аналізу.

них структур речень, що входять в ПМО; - послідовність об'єктово-семантичних структур речень;

$\mathrm{S}^{\mathrm{a}}$ - послідовність акторно-семантичних структур речень; ${ }^{\circ}$ - послідовність онтографів; Ф - формально-логічне представлення ПМО; 1 - графемно-морфологічний аналіз; 2 - синтаксичний аналіз; 3 - об'єктово-семантичний аналіз; 4 - акторно-семантичний аналіз; 5 - онтологічний аналіз; 6 - аналіз неоднозначностей; 7 - онтолого-семантичний аналіз; 8 - формально-логічний аналіз.
Нижче акцентуємо увагу на аналізі неоднозначностей , притаманних будь-якому ПМО. Вказаний аналіз виконується ітеративно завдяки зворотному зв'язку від блоку побудови онтографів О.

Однією із суттєвих складових пропонованого підходу $€$ потрійний аналіз неоднозначностей, два з яких описано вище, а третій, найбільш складний, опишемо нижче.

На перших двох етапах виконуються спрощення для неоднозначностей морфологічного та синтактико-семантичного типу. При цьому відповідні записи 
у морфологічній таблиці ПМО видаляються. Перехід до третього етапу аналізу неоднозначностей (неоднозначностей, що мають контекстно-семантичні витоки) виконується тоді, коли для будь-якої словоформи морфологічній таблиці ПМО залишилось два (чи більше) записи.

Спочатку виконується спроба побудувати акторно-семантичне відображення деякого речення ПМО для перших записів словоформ (із морфологічної таблиці), що входять у речення. При цьому інтерпретатор аналізує відповідний онтограф речення згідно 3 правилами бази знань природної мови. Якщо результат інтерпретації є "істина", то формується акторносемантична структура речення. Якщо ж результатом є "хибність", то активується зворотний зв'язок від онтологічного блоку до блоку морфологічного

\section{Література}

1. Ножов И. М. Морфологическая и синтаксическая обработка текста (модели и программы) : дис. ... кандидата техн. наук / Ножов И. М. - М., 2003. - 140 с.

2. Гладун В. П. Процессы формирования новых знаний / Гладун В. П. - София : Педагог 6, 1994. - 192 с.

3. Тестелец Я. Г. Введение в общий синтаксис / Тестелец Я. Г. - М. : РГГУ 2001. - 798 с.

4. Попов Э. В. Общение с ЭВМ на естественном языке / Попов Э. В. - М. : Наука, 1982. - 360 с.

5. Найханова Л. В. Основные аспекты построения онтологий верхнего уровня и предметной области / Найханова Л. В. // Интернет-порталы: содержание и технологии, ФГУ ГНИИ ИТТ "Информатика". - М. : Просвещение, 2005. - С. 452-479. 6. Добров Б. В. Методы и средства автоматизированного проектирования прикладной онтологии / [Добров Б. В., Лукашевич Н. В., Невзорова О. А., Федунов Б. Е.] // Теория и системы управления. - 2004. - .№ 2. - С. 58-68.

7. Величко В. Автоматизированное создание тезауруса терминов предметной области для локальных поисковых систем. "Knowledge - Dialogue - Solution" International Book Series "INFORMATION SCIENCE \& COMPUTING", Number 15 / В. Величко, П. Волошин, С. Свитла. - Sofia : FOI ITHEA, Bulgaria, 2009. - P. 24-31.

8. Палагин А. В. К проектированию онтологоуправляемой информационной системы с обработкой естественно-языковых объектов / А. В. Палагин, Н. Г. Петренко // Математические машины и системы. - 2008. - № 2. - С. 14-23. 9. Рыков В. В. Управление знаниями / Рыков В. В. - Режим доступа: http://ryk-kypc2.narod.ru/part2.doc. аналізу (на рис. 10 позначено цифрою 6). Однією 3 умов при формуванні значення істинності може бути умова зв'язності онтографа.

Висновки. 1. Одним 3 перспективних шляхів підвищення ефективності кваліфікованої медичної допомоги є використання сучасних інформаційних технологій, зокрема дистанційного доступу до розподілених систем знань.

2. Запропоновано глосарій термінів предметної області.

3. Запропонована блок-схема узагальненого алгоритму лінгвістичного аналізу та формалізації деякого ПМО у вигляді послідовності етапів графемно-морфологічного, синтаксичного, об'єктово-семантичного, акторно-семантичного, онтологічного, онтолого-семантичного та формально-логічного аналізу.

10. Гладун В. П. Конспектирование естественно-языковых текстов. Proceedings of the XI-th International Conference "Knowledge-Dialogue-Solution"(KDS'2005) / В. П. Гладун, В. Ю. Величко. - Varna, 2005. - Vol. 2. - Р. 344-347.

11. Палагін О. В. Модель категоріального рівня мовно-онтологічної картини світу / О. В. Палагін, Н. Г. Петренко // Математичні машини й системи. - 2006. - № 3. - С. 91-104. 12. Палагін О. В. Архітектурно-онтологічні принципи розбудови інтелектуальних інформаційних систем / О. В. Палагін, Н. Г. Петренко // Математичні машини і системи. 2006. - № 4. - C. 15-20.

13. Palagin A. Informational model of natural language processing / [Palagin A., Gladun V, Petrenko N. et al.] // International Journal Information Technologies and Knowledge . - 2008. - Vol. 2. - P. 5-6.

14. Палагин А. В. К вопросу системно-онтологической интеграции знаний предметной области / А. В. Палагин, Н. Г. Петренко // Математические машины и системы. - 2007. - № 3, 4. - С. 63-75.

15. Засоби доступу до джерел знань, та їх використання в учбовому процесі педагогічного навчального закладу : методичні рекомендації ; за ред. чл.-кор. НАН України С.О. Довгого і к. т. н. О. Є. Стрижака. - К. : АПН, ІОД, 2009. - 66 с. 16. Стрижак О. Є. Комп'ютерні тезауруси як технологічна платформа створення авторських методик викладання предметних дисциплін / Стрижак О. Є. в кн. Актуальні проблеми психології: Психологічна теорія і технологія навчання; за ред. С. М. Максименка, М. Л. Смульсон. - К. : НПУ ім. М. П. Драгоманова, 2009. - Т. 8, вип. 6. - С. 259-266. 